\title{
Efektivitas Penerapan Pembelajaran Daring Terhadap Tingkat Pemahaman Belajar Mahasiswa Dimasa Pandemi Covid-19
}

\author{
Endang Suryana $^{1}$, Dedeh Supriyanti ${ }^{2}$, Fadhillah Nur Widjajanti ${ }^{* 3}$ \\ ${ }^{1}$ Program Studi Sistem Informasi Fakultas Sains dan Teknologi Universitas Raharja, ${ }^{2}$ Program \\ Studi Teknik Informatika Fakultas Sains dan Teknologi Universitas Raharja, ${ }^{3}$ Program Studi \\ Komputerisasi Akuntansi Fakultas Sains dan Teknologi Universitas Raharja \\ E-mail: ${ }^{1}$ suryana@ raharja.info, ${ }^{2}$ dedeh@ raharja.info, ${ }^{* 3}$ fadhillah.nur@ raharja.info
}

\begin{abstract}
Abstrak
Sejak bulan Maret 2020, telah diberlakukan pembelajaran daring khususnya pada perguruan tinggi di Indonesia sebagai dampak dari pandemi Covid-19. Dan dalam pelaksanaannya beberapa hambatan pun terjadi, sehingga memungkinkan juga berdampak pada pemahaman mahasiswa terhadap materi bahan ajar yang disampaikan. Oleh karena itu, tujuan dari penelitian ini untuk membantu mengetahui keefektifan sistem pembelajaran daring yang selama ini telah diterapkan. Penelitian dilakukan menggunakan metode kualitatif dengan menyebarkan kuesioner melalui sosial media dan telah direspon oleh 197 Mahasiswa baik yang berasal dari Perguruan Tinggi Negeri maupun Perguruan Tinggi Swasta. Kemudian data dianalisis menggunakan teknik analisis Miles dan Huberman yang menghasilkan bahwa sistem pembelajaran daring yang diterapkan sudah cukup efektif sehingga Mahasiswa secara cukup baik dapat memahami materi bahan ajar yang telah disampaikan dengan kondisi banyak dari Mahasiswa melakukan pembelajaran daring di rumah dengan menggunakan laptop atau komputer dan paket data pribadi dengan kondisi sinyal sedang.
\end{abstract}

Kata Kunci-Pembelajaran Daring, Efektivitas, Pemahaman Materi.

\begin{abstract}
Since March 2020, online learning has been implemented, especially in universities in Indonesia as a result of the Covid-19 pandemic. And in its implementation some obstacles also occur, so that it is possible to also have an impact on students' understanding of the teaching materials delivered. Therefore, the purpose of this research is to help determine the effectiveness of online learning systems that have been implemented. The research was conducted using qualitative method by distributing questionnaires through social media and has been responded by 197 students both from State Universities and Private Universities. Then the data were analyzed using Miles and Huberman analysis techniques that resulted in the online learning system being implemented effectively enough so that students could understand the teaching materials that had been delivered with the condition of many students doing online learning at home using laptops or computers and personal data packages with moderate signal conditions.
\end{abstract}

Keywords-Online Learning, Effectiveness, Understanding of the Material. 


\section{PENDAHULUAN}

Pada saat ini, wabah Covid-19 telah menjadi tantangan tersendiri untuk 215 negara di penjuru dunia, termasuk salah satunya yaitu di bidang pendidikan, khususnya perguruan tinggi. Pemerintah Indonesia sendiri telah memberlakukan beberapa protokol seperti social and physical distancing, memakai masker serta untuk selalu mencuci tangan sebagai bentuk pencegahan penularan Covid-19. Pelarangan kepada seluruh perguruan tinggi dalam melaksanakan tatap muka pun juga diberlakukan oleh Kementerian Pendidikan dan Kebudayaan, sehingga perkuliahan diperintahkan untuk diselenggarakan secara daring berdasarkan Surat Edaran Kemendikbud Dikti No. 1 tahun 2020 [1].

Berbagai jenis perangkat lunak/platform mulai digunakan untuk perkuliahan daring yang terhitung mulai pada periode bulan Maret 2020. Learning management system, perangkat lunak kolaborasi ataupun video conference adalah jenis-jenis perangkat lunak yang digunakan [2]. Learning management system adalah sistem atau aplikasi e-learning yang memvirtualisasikan proses belajar mengajar yang sudah terhubung dengan internet di antaranya meliputi; sistem penilaian, forum diskusi, sistem ujian online, dan pembuatan materi di dalamnya [3]. Google Classroom dan portal-portal e-learning milik perguruan tinggi merupakan contoh dari jenis perangkat lunak learning management system.

Kemudian, adanya pengembangan media ajar berbasis online menjadikan pengaksesan informasi secara fleksibel kapan dan di mana saja [4]. Dengan itu, dukungan-dukungan perangkat device seperti smartphone, tablet, laptop dan komputer juga sangatlah dibutuhkan dalam pelaksanaan pembelajaran daring ini guna mengakses platform yang tersedia [5]. Serta perlu diketahui, penggunaan internet dalam pembelajaran daring merupakan salah satu cara guna meningkatkan keterampilan serta pengetahuan seorang peserta didik maupun pengajar [6]. Karena lengkapnya penunjang seperti fasilitas, informasi dan sumber pembelajaran yang telah tersedia di internet saat ini [7]. Serta memberikan dapat peluang kepada para developer untuk berlomba - lomba dalam menciptakan aplikasi yang dapat menunjang proses belajar mengajar secara online, dan juga membuat para pengajar lebih kreatif dalam membuat pembelajaran menjadi menarik [8].

Namun dalam pembelajaran daring ini, perlu dipahami bahwa ada beberapa permasalahan yang menjadi hambatan dalam pelaksanaannya. Beberapa keluhan dan hambatan yang dirasakan oleh mahasiswa secara umum yaitu jaringan internet yang tidak stabil, bahan materi yang belum bisa disampaikan secara maksimal setiap pertemuan, sarana media pendukung yang minim semasa aktivitas daring, dan sulitnya mengontrol aktivitas kegiatan belajar secara langsung. Oleh sebab itu, solusi dan berbagai langkah yang diambil untuk jalan keluar di masa sekarang ini sangatlah diperlukan untuk membantu meningkatkan pemahaman materi oleh mahasiswa [9].

Selain itu, karakteristik dan faktor lingkungan belajar peserta didik dapat menyebabkan pembelajaran online tidak menjadikan indikasi dari semua literatur membuat peserta didik tersebut akan sukses [10]. Tetapi, motivasi para peserta didik lah yang menjadikan keberhasilan dari suatu pembelajaran yang dterapkan [11]. Dan juga, tujuan yang menjadi arah utama perilaku peserta didik adalah pengertian dari suatu motivasi [12]. Dalam motivasi, aktivitas merupakan hal yang sangat penting untuk memberikan dorongan baik secara mental maupun fisik [13]. Hal ini juga dapat mempengaruhi seseorang dalam mempelajari apa yang dipelajari, bagaimana caranya serta kapan waktu belajarnya [14].

Sebelumnya terdapat penelitian yang dilakukan oleh Juliantari et al (2018) dengan menggunakan game interaktif dalam mengevaluasi untuk memanfaatkan teknologi informasi. Di mana hasilnya yaitu, 
apabila suatu teknologi informasi diunakan dengan tepat dan baik maka hal tersebut dapat menunjang suatu pembelajaran [15]. Dan pada penelitian ini, penulis memiliki tujuan untuk membantu melakukan evaluasi terhadap keefektifan sistem perkuliahan daring guna meningkatkan pemahaman materi bahan ajar oleh mahasiswa.

\section{METODE PENELITIAN}

Jenis penelitian yang digunakan adalah penelitian kualitatif. Tujuan dilakukannya penelitian ini yaitu untuk mengetahui seberapa efektifkah penerapan sistem pembelajaran yang telah dilakukan selama perkuliahan daring ini terhadap tingkat pemahaman materi yang diserap oleh mahasiswa. Penelitian dilakukan dengan mengadakan survei kepada mahasiswa mengenai tingkat pemahaman yang didapatkan selama perkuliahan daring dilakukan serta kondisi responden saat dilakukannya perkuliahan daring tersebut. Survei dibuat menggunakan google form lalu disebarkan kepada mahasiswa melalui media Whatsapp, Instagram dan Twitter. Terdapat 197 orang subyek yang telah memberikan respons terhadap survei yang telah disebarkan.

Subyek penelitian yang disurvei adalah mahasiswa baik yang berasal dari PTN (Perguruan Tinggi Negeri) maupun PTS (Perguruan Tinggi Swasta) yang menerapkan sistem perkuliahan daring dan dikelompokkan berdasarkan subyek penelitian. Subyek penelitian yang telah didapatkan yaitu mahasiswa semester 1 sampai dengan mahasiswa semester 9 dari berbagai fakultas dan jurusan, di antaranya; 159 mahasiswa S1 (Strata 1) dan 38 mahasiswa Diploma, serta 167 mahasiswa berjenis kelamin perempuan dan 30 mahasiswa berjenis kelamin laki - laki.

Hasil dari survei ini dikelompokkan menjadi dua bagian, yaitu: (1) Tingkat pemahaman belajar yang didapatkan oleh mahasiswa selama pembelajaran daring; (2) Kondisi mahasiswa selama melakukan proses pembelajaran daring. Penulis menggunakan model analisis Miles \& Huberman (1994) untuk melakukan analisis data penelitian yang terdiri dari 3 tahapan, di antaranya: (1) reduksi data; (2) display data; (3) penarikan dan verifikasi kesimpulan.

Tahap reduksi data pada analisis data penelitian yaitu tahap mengumpulkan informasi yang diperlukan kemudian datanya dikelompokkan. Setelah itu pada tahap display data, hanya memaparkan data yang diperlukan saja. Kemudian pada tahap penarikan dan verifikasi kesimpulan adalah tahap dilakukannya interpretasi data penelitian yang setelah itu akan digunakan untuk menarik kesimpulan yang didasari oleh fenomena yang didapatkan [16].

\section{HASIL DAN PEMBAHASAN}

\subsection{Tingkat pemahaman belajar yang didapatkan oleh mahasiswa selama pembelajaran daring}

Lembaga harus memahami beberapa aspek seperti salah satu diantaranya yaitu peralatan pendukung internet dalam pembelajarannya [17]. Selain itu juga, dari seluruh tujuan pembelajaran jika peserta didik mampu menguasai minimal $65 \%$ pembelajaran, maka ia akan dipandang tuntas dalam belajar. Lalu, untuk melihat keberhasilan pembelajaran, minimal $65 \%$ yang harus dicapai oleh peserta didik dan jika dilihat dari jumlah siswa maka sekurangkurangnya yaitu $85 \%$ [18].

Berikut ini merupakan hasil rekapitulasi survei yang dilakukan penulis terkait keefektifan tentang penerapan pembelajaran daring terhadap tingkat pemahaman belajar yang didapatkan oleh 197 Mahasiswa, baik yang berasal dari PTN ataupun PTS. 
Tabel 1. Rekapitulasi hasil survei mengenai tingkat pemahaman Mahasiswa selama pembelajaran daring

\begin{tabular}{llllll}
\hline No Pertanyaan & \multicolumn{5}{c}{ Skala } \\
\cline { 2 - 6 } & $\begin{array}{l}\text { Sangat } \\
\text { kurang }\end{array}$ & Kurang & Cukup & Baik & Sangat \\
& baik & & baik
\end{tabular}

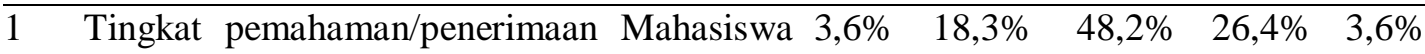
terhadap materi bahan ajar (mata kuliah) yang disampaikan oleh dosen selama perkuliahan daring

2 Tingkat pemahaman Mahasiswa terhadap $\quad 1,5 \% \quad 11,7 \% \quad 45,7 \% \quad 37,1 \% \quad 4,1 \%$ jawaban yang diberikan oleh dosen terkait pertanyaan yang diajukan Mahasiswa

3 Pendapat Mahasiswa terkait cara dosen dalam $2 \% \quad 15,2 \% \quad 47,2 \% \quad 28,4 \% \quad 7,1 \%$ menyampaikan contoh - contoh terhadap pembelajaran yang dibahas

4 Ketepatan waktu memulai dan berakhirnya $3 \% \quad 17,8 \% \quad 30,5 \% \quad 32,5 \% \quad 16,2 \%$ mata kuliah selama pembelajaran daring

6 Ketepatan mahasiswa dalam mengerjakan $2 \% \quad 3,6 \% \quad 22,3 \% \quad 35,5 \% \quad 36,5 \%$ tugas sesuai waktu yang diberikan oleh dosen selama pembelajaran daring

7 Tingkat keefektifan atau kebijakan absensi $\quad 3 \% \quad \begin{array}{lllll}16,2 \% & 29,4 \% & 26,4 \% & 24,9 \%\end{array}$ yang diterapkan selama pembelajaran daring

8 Pendapat mahasiswa terkait sistem penilaian $0 \% \quad 8,1 \% \quad 34 \% \quad 42,6 \% \quad 15,2 \%$ yang dilakukan dosen selama pembelajaran daring

9 Hasil nilai yang didapatkan oleh Mahasiswa $2 \% \quad 5,1 \% \quad 31 \% \quad 43,1 \% \quad 18,8 \%$ selama pembelajaran daring

10 Tingkat semangat yang dimiliki Mahasiswa $\quad 13,2 \% \quad 24,9 \% \quad 34,5 \% \quad 19,8 \% \quad 7,6 \%$ selama pembelajaran daring

Pada tingkat pemahaman Mahasiswa terhadap materi bahan ajar (mata kuliah) yang disampaikan oleh dosen selama pembelajaran daring, Mahasiswa paling banyak berpendapat bahwa mereka sudah cukup paham terhadap materi bahan ajar yang disampaikan. Sedangkan Mahasiswa yang merasa sangat kurang paham terhadap materi bahan ajar yang disampaikan hanya sekitar 3,6\% dan hal tersebut sebanding dengan Mahasiswa yang merasa sangat paham dengan materi bahan ajar yang disampaikan oleh dosen. Dapat ditarik kesimpulan, yaitu banyak 
Mahasiswa yang sudah cukup paham terhadap materi bahan ajar yang disampaikan dengan jumlah persentase sebanyak $48 \%$.

Pada saat waktu pembelajaran dilakukan, biasanya dosen memberikan kesempatan kepada Mahasiswa untuk mengajukan pertanyaan. Pada tingkat pemahaman terhadap jawaban yang diberikan dosen atas pertanyaan yang diajukan Mahasiswa ini, Mahasiswa paling banyak memvoting bahwa mereka sudah cukup baik dalam memahami jawaban yang diberikan oleh dosen atas pertanyaan yang diajukan. Sedangkan sangat sedikit yang merasa sangat kurang paham atas jawaban yang diberikan dosen, yaitu hanya sebanyak 1,5\% Mahasiswa. Maka dapat ditarik kesimpulan, bahwa Mahasiswa sudah cukup paham terhadap jawaban yang diberikan dosen atas pertanyaan yang diajukan Mahasiswa dengan persentase sejumlah 45,7\%.

Lalu, terkait cara penyampaian dosen terhadap contoh - contoh dalam pembelajaran yang dibahas, sangat banyak atau sejumlah $47,2 \%$ Mahasiswa yang berpendapat bahwa dosen sudah cukup baik dalam menyampaikannya. Sedangkan sangat sedikit atau hanya sekitar $2 \%$ Mahasiswa yang berpendapat bahwa dosen sangat kurang dalam menyampaikan contoh contoh yang ada dalam pembelajaran yang dibahas. Sehingga, kesimpulannya adalah cara dosen sudah cukup baik dalam menyampaikan contoh - contoh yang ada dalam pembelajaran yang dibahas.

Kedisiplinan waktu juga merupakan faktor yang dapat mempengaruhi tingkat pemahaman seseorang. Sehingga diharapkan tidak adanya waktu perkuliahan yang bentrok dengan mata kuliah yang lainnya atau materi bahan ajar yang tidak dapat disampaikan secara maksimal akibat telatnya waktu memulai perkuliahan. Pada ketepatan waktu memulai dan berakhirnya mata kuliah selama pembelajaran daring ini, sangat banyak Mahasiswa yang berpendapat bahwa ketepatan waktu perkuliahan sudah dilakukan dengan baik. Sedangkan sangat sedikit yang berpendapat bahwa ketepatan waktu perkuliahan dilakukan dengan sangat kurang baik. Dapat ditarik kesimpulan bahwa banyak Mahasiswa atau sejumlah 32,5\% Mahasiswa berpendapat bahwa ketepatan waktu memulai dan berakhirnya perkuliahan selama daring sudah baik.

Kemudian, kerap didengar terkait keluhan Mahasiswa mengenai banyaknya tugas perkuliahan yang diberikan selama perkuliahan daring ini. Terkait ketepatan mahasiswa dalam mengerjakan tugas sesuai waktu yang diberikan oleh dosen selama pembelajaran daring ini, Mahasiswa paling banyak memvoting bahwa mereka masih selalu dapat tepat waktu dalam menyelesaikan tugas yang diberikan, yaitu dengan jumlah persentase sebanyak 36,5\% Mahasiswa. Sedangkan sangat sedikit atau hanya sekitar 2\% Mahasiswa yang tidak dapat tepat waktu dalam mengerjakan tugas yang diberikan. Dapat ditarik kesimpulan, walaupun banyaknya tugas yang diberikan selama perkuliahan daring ini, namun banyak Mahasiswa yang masih selalu dapat menyelesaikan tugas yang diberikan secara tepat waktu.

Absensi yang diterapkan juga diharapkan dapat efektif sehingga tidak mengganggu proses belajar - mengajar yang dilakukan selama perkuliahan daring. Pada keefektifan atau kebijakan absensi yang dilakukan selama perkuliahan daring ini, paling banyak Mahasiswa yang berpendapat bahwa absensi yang dilakukan sudah cukup baik. Sedangkan sangat sedikit atau hanya sekitar 3\% Mahasiswa saja yang berpendapat bahwa absensi yang dilakukan sangat kurang efektif. Maka kesimpulannya adalah bahwa absensi yang dilakukan sudah cukup baik dengan jumlah sekitar 29,4\%.

Pada sistem penilaian yang diterapkan oleh dosen selama pembelajaran daring, Mahasiswa paling banyak memvoting bahwa penerapan sistem penilaian yang diberlakukan oleh dosen sudah baik. Sedangkan hanya sedikit sekali bahkan hanya $0 \%$ yang berpendapat bahwa sistem penilaian yang diterapkan oleh dosen sangat kurang. Sehingga dapat ditarik kesimpulan bahwa penerapan sistem penilaian sudah baik dengan jumlah persentase sebanyak $42,6 \%$.

Kemudian, hasil nilai yang didapatkan oleh Mahasiswa merupakan tolak ukur atas keberhasilan Mahasiswa dalam memahami materi bahan ajar yang disampaikan oleh dosen selama perkuliahan daring. Apabila hasil nilai yang didapatkan Mahasiswa itu baik, maka otomatis pemahaman Mahasiswa terhadap materi bahan ajar yang disampaikan juga baik. Dan 
pada hasil nilai yang didapatkan Mahasiswa, banyak sekali Mahasiswa yang sudah mendapatkan hasil nilai yang baik yaitu sekitar $43,1 \%$ Mahasiswa. Sedangkan paling sedikit hanya sekitar 2\% Mahasiswa yang mendapatkan nilai yang sangat kurang. Maka kesimpulannya adalah banyak Mahasiswa yang telah berhasil memahami materi bahan ajar yang telah disampaikan oleh dosen selama perkuliahan daring ini.

Dan terakhir, kesemangatan juga merupakan salah satu faktor Mahasiswa mampu dalam menyerap pembelajaran yang dilakukan. Mahasiswa paling banyak yang merasa bahwa mereka sudah cukup semangat dalam melakukan perkuliahan daring ini yaitu sekitar $34,5 \%$. Sedangkan sangat sedikit sekali atau sekitar 7,6\% mahasiswa yang merasa sangat semangat dalam melakukan perkuliahan daring dibandingkan Mahasiswa yang merasa sangat kurang semangat dalam perkuliahan daring ini yaitu sekitar $13,2 \%$. Dapat ditarik kesimpulannya yakni bahwa walaupun sudah banyak mahasiswa yang merasa cukup semangat dalam menjalani perkuliahan daring ini, namun Mahasiswa yang merasa sangat semangat lebih sedikit dibandingkan Mahasiswa yang merasa sangat tidak semangat dalam melakukan perkuliahan daring ini. Sehingga, untuk para Mahasiswa perlu untuk meningkatkan kesemangatannya lagi dalam perkuliahan daring ini.

\subsection{Kondisi Mahasiswa saat melakukan pembelajaran daring}

Banyak sekali faktor - faktor yang mempengaruhi tingkat pemahaman Mahasiswa selama penerapan dalam proses pembelajaran daring. Selain metode mengajar yang dilakukan oleh dosen, media atau kondisi Mahasiswa juga menjadi faktor yang mempengaruhi tingkat pemahaman Mahasiswa terhadap materi bahan ajar yang disampaikan oleh dosen.

Berikut ini merupakan hasil survei yang dilakukan oleh penulis terkait kondisidari 197 Mahasiswa yang menjadi responden saat melakukan pembelajaran daring.

\subsubsection{Lokasi Mahasiswa saat melakukan daring}

Kondisi lingkungan sekitar atau kondisi keramaian sekitar selama pembelajaran daring juga mempengaruhi tingkat pemahaman seseorang terhadap pembelajaran yang dilakukan. Mahasiswa paling banyak memilih di rumah sebagai tempat untuk melakukan daring. Lalu 2\% atau 4 Mahasiswa yang melakukan perkuliahan daring di tempat kerja. Serta 1,5\% atau sebanyak 3 Mahasiswa melakukan di tempat umum. Maka dari hasil survei yang didapat berdasarkan lokasi Mahasiswa ini, kebanyakan Mahasiswa sudah melakukan perkuliahan daring di rumah.

Tabel 2. Hasil survei lokasi mahasiswa saat melakukan daring.

\begin{tabular}{lll}
\hline No & Lokasi & Persentase (\%) \\
\hline 1 & Rumah & $96,4 \%$ \\
2 & Tempat kerja & $2 \%$ \\
3 & Tempat umum & $1,5 \%$ \\
\hline
\end{tabular}


Lokasi saat melakukan perkuliahan

197 tanggapan

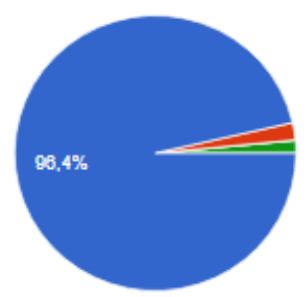

- Di rumah

- Di tempat keria

Di tempat umum

- Di tempat umum (ex: Cafe, dII)

Gambar 1. Bukti survei Lokasi Mahasiswa saat melakukan perkuliahan daring

\subsubsection{Media yang digunakan Mahasiswa selama pembelajaran daring}

Mahasiswa paling banyak memilih menggunakan Laptop/PC (Personal Computer) sebagai media yang digunakan untuk pembelajaran daring. Sedangkan Mahasiswa yang menggunakan smartphone sebanyak 45,7\%. Serta Mahasiswa paling sedikit memilih menggunakan tablet yaitu hanya sekitar $0,5 \%$ atau 1 orang Mahasiswa saja yang menggunakan tablet sebagai media yang digunakan selama daring. Maka kesimpulannya yaitu banyak Mahasiswa yang merasa lebih efektif menggunakan laptop untuk melakukan perkuliahan daring ini dibandingkan menggunakan smartphone apalagi tablet.

Tabel 3. Hasil survei media yang digunakan untuk belajar

\begin{tabular}{lll}
\hline No & Media & Persentase (\%) \\
\hline 1 & Laptop/PC & $53,8 \%$ \\
2 & Smartphone & $45,7 \%$ \\
3 & Tablet & $0,5 \%$
\end{tabular}

Media yang digunakan

197 tanggapan

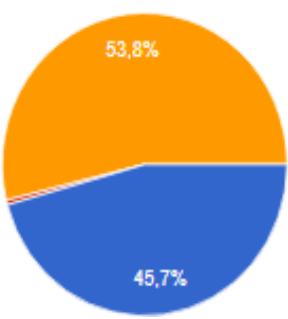

Smartphone/handphone

Tablet

Laptop/PC

Gambar 2. Bukti survei Media yang digunakan Mahasiswa saat melakukan perkuliahan daring

\subsubsection{Jenis koneksi internet yang digunakan Mahasiswa selama pembelajaran daring}

Sebanyak 50,8\% atau sejumlah 100 Mahasiswa Menggunakan jenis koneksi internet paket data. Sedangkan sekitar 49,2\% atau sebanyak 97 Mahasiswa telah menggunakan jenis 
koneksi internet wifi. Dan kesimpulannya adalah masih banyak Mahasiswa yang masih menggunakan paket data pribadi sebagai jenis koneksi internet yang digunakan.

Tabel 4. Hasil survei jenis koneksi internet yang digunakan

\begin{tabular}{lll}
\hline No & Media & Persentase (\%) \\
\hline 1 & Paket data & $50,8 \%$ \\
2 & Wifi & $49,2 \%$ \\
& & \\
\hline
\end{tabular}

Jenis koneksi internet yang digunakan

197 tanggapan

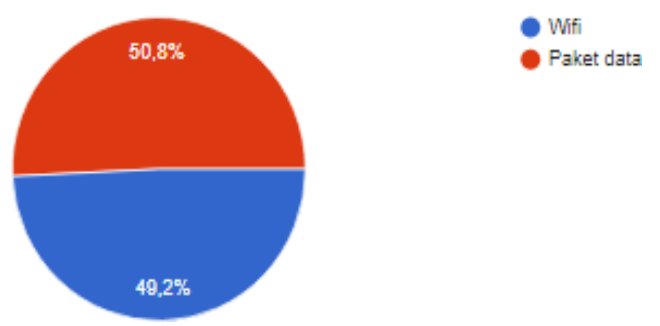

Gambar 3. Bukti survei Jenis koneksi Internet yang digunakan oleh Mahasiswa saat pembelajaran daring

\subsubsection{Kondisi sinyal internet Mahasiswa}

Kondisi sinyal pada saat melakukan pembelajaran daring juga sangatlah mempengaruhi Mahasiswa untuk memahami materi bahan ajar yang disampaikan oleh dosen. Karena jika kondisi sinyal lemah saat pembelajaran daring, lalu koneksi terputus, maka hal tersebut dapat mengganggu proses belajar - mengajar dan pastinya sangat akan mempengaruhi terhadap tingkat pemahaman yang nantinya akan diserap oleh Mahasiswa.

Terdapat 23,9\% Mahasiswa atau 47 dari 197 Mahasiswa yang memiliki kondisi sinyal kuat. Sedangkan Mahasiswa paling banyak yang memiliki kondisi sinyal sedang yaitu sekitar 71,6\% atau sebanyak 141 Mahasiswa. Dan sekitar 4,6\% atau sejumlah 9 Mahasiswa yang memiliki kondisi sinyal lemah. Maka kesimpulannya adalah kondisi sinyal mahasiswa yaitu sinyal sedang, sehingga banyak yang tidak terganggu terkait kondisi sinyal.

Tabel 5. Hasil survei kondisi sinyal internet Mahasiswa

\begin{tabular}{lll}
\hline No & Kondisi Sinyal Internet & Persentase (\%) \\
\hline 1 & Sinyal kuat & $23,9 \%$ \\
2 & Sinyal sedang & $71,6 \%$ \\
3 & Sinyal lemah & $4,6 \%$
\end{tabular}


Kondisi sinyal internet

197 tanggapan

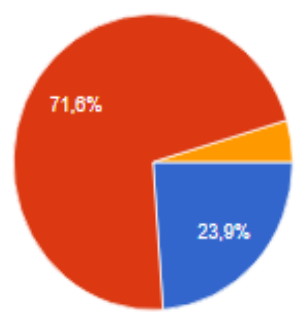

Sinyal kuat

- Sinyal sedang

Sinyal lemah

Gambar 4. Bukti survei Jenis koneksi Internet yang digunakan oleh Mahasiswa saat pembelajaran daring

\subsubsection{Platform yang digunakan selama pembelajaran daring}

Sebanyak 61,4\% Mahasiswa menggunakan platform zoom meeting ataupun google meet di kampusnya. Lalu sekitar 14,7\% Mahasiswa hanya menggunakan platform whatsapp saja, kemudian sebanyak $6,1 \%$ Mahasiswa saja yang menggunakan platform edmodo ataupun google classroom. Serta terdapat sebanyak 17,8\% Mahasiswa yang menggunakan platform lain dalam proses pembelajaran. Dapat ditarik kesimpulan bahwa banyak Mahasiswa yang menggunakan platform zoom meeting ataupun google meeting selama pembelajaran daring.

Tabel 6. Hasil survei platform yang digunakan

\begin{tabular}{lll}
\hline No & Platform yang digunakan & Persent \\
\hline 1 & Whatsapp & $6,1 \%$ \\
2 & Zoom meeting/Google meet & $61,4 \%$ \\
3 & Edmodo/Google classroom & $14,7 \%$ \\
4 & Lainnya & $17,8 \%$
\end{tabular}

Platform yang digunakan

197 tanggapan

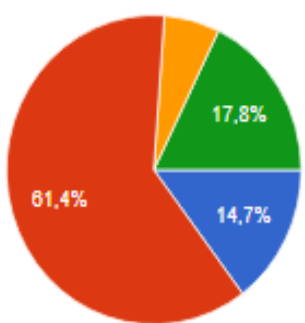

Whatsapp Group

Zoom meeting / Google meet

- Edmodo / Google classroom

- Lainnya

Gambar 5. Bukti survei Platfrom yang digunakan oleh Mahasiswa selama pembelajaran daring. 


\section{KESIMPULAN}

Wabah Covid-19 yang sedang melanda saat ini, telah memberikan dampak terhadap berlangsungnya proses belajar - mengajar di Indonesia, khususnya di perguruan tinggi. Sehingga PTN maupun PTS diminta oleh Kementerian Pendidikan dan Kebudayaan untuk memberlakukan sistem pembelajaran daring sebagai salah satu upaya untuk memutus rantai penularan wabah Covid-19. Seperti yang kita ketahui, karena pemberlakuan sistem pembelajaran daring yang secara tiba - tiba, mengakibatkan beberapa PTN ataupun PTS kurang siap untuk menghadapi sistem pembelajaran daring saat ini. Sehingga, memungkinkan untuk memberikan dampak terhadap tingkat pemahaman Mahasiswa pada materi bahan ajar (Mata Kuliah) yang telah disampaikan oleh dosen.

Namun, setelah hampir 6 (enam) bulan diberlakukannya sistem pembelajaran daring terhitung sejak Maret 2020 lalu, telah banyak PTN ataupun PTS serta pemerintah yang berupaya untuk memperbaiki sistem pembelajaran daring supaya menjadi lebih efektif sehingga meminimalisir kemungkinan dampak terhadap tingkat pemahaman Mahasiswa pada materi bahan ajar yang disampaikan. Pada penelitian ini, penulis telah melakukan survei dengan cara menyebarkan kuesioner melalui whatsapp, instagram dan twitter. Terdapat 197 responden yaitu Mahasiswa yang berkuliah di PTN ataupun PTS dari berbagai fakultas dan jurusan, yang diantaranya 159 mahasiswa S1 (Strata 1) dan 38 mahasiswa Diploma, serta 167 mahasiswa berjenis kelamin perempuan dan 30 mahasiswa berjenis kelamin laki - laki. Berdasarkan hasil survei yang telah didapat penulis, dapat disimpulkan bahwa :

1. Pemahaman Mahasiswa terkait bahan ajar materi, jawaban yang diberikan dosen mengenai pertanyaan yang diajukan, serta contoh - contoh yang disampaikan oleh dosen mengenai materi bahan ajar yang dibahas sudah cukup baik diterima dan dipahami oleh Mahasiswa selama pembelajaran daring saat ini.

2. Ketepatan waktu memulai dan berakhirnya perkuliahan, menurut Mahasiswa juga telah dilakukan dengan baik. Mahasiswa juga selalu dapat tepat waktu dalam mengerjakan tugas sesuai dengan waktu yang telah ditentukan.

3. Tingkat keefektifan absensi yang diberlakukan selama pembelajaran daring sudah cukup baik. Sedangkan sistem penilaian dan hasil nilai yang didapatkan oleh Mahasiswa selama pembelajaran daring yaitu sudah baik.

4. Tingkat kesemangatan Mahasiswa sudah cukup baik selama mengikuti perkuliahan daring.

Selain itu, faktor eksternal seperti kondisi Mahasiswa selama perkuliahan daring, juga sangat berpengaruh terhadap tingkat pemahaman materi bahan ajar yang disampaikan oleh dosen. Dari hasil survei yang didapatkan, yakni kebanyakan Mahasiswa melakukan perkuliahan daring di rumah dengan menggunakan Laptop/PC sebagai media untuk berlangsungnya perkuliahan daring. Sedangkan untuk jenis koneksi internet, banyak mahasiswa yang masih menggunakan data pribadi sehingga Mahasiswa merasa keberatan karena membutuhkan banyak dana terlebih lagi banyak Mahasiswa yang melakukan pembelajaran daring menggunakan platform zoom meeting/google meet yang dapat menghabiskan banyak kuota. Namun untuk kondisi sinyal yang dialami oleh Mahasiswa yaitu sinyal sedang.

\section{SARAN}

Untuk itu, penulis menyarankan dalam meningkatkan keefektifan penerapan pembelajaran daring terhadap tingkat pemahaman belajar Mahasiswa di masa pandemi Covid19 ini, salah satunya yaitu dengan cara dosen menerapkan pretest sebelum melakukan pembelajaran untuk mengingat kembali pelajaran sebelumnya, serta menerapkan post test setelah melakukan pembelajaran untuk mengevaluasi seberapa paham Mahasiswa terkait materi bahan ajar yang telah diajarkan pada hari tersebut. 


\section{DAFTAR PUSTAKA}

[1] A. Sadikin and A. Hamidah, "Pembelajaran Daring di Tengah Wabah Covid-19: (Online Learning in the Middle of the Covid-19 Pandemic)," BIODIK, vol. 6, no. 2 SE-, pp. 214-224, Jun. 2020, doi: 10.22437/bio.v6i2.9759.

[2] A. Irhandayaningsih, "Pengukuran Literasi Digital Pada Peserta Pembelajaran Daring di Masa Pandemi COVID-19," Anuva J. Kaji. Budaya, Perpustakaan, dan Inf., vol. 4, no. 2, pp. 231-240, 2020.

[3] A. Sudibjo, "PENGGUNAAN MEDIA PEMBELAJARAN IPA BERBASIS GOOGLE CLASSROOM PADA MATERI ALAT OPTIK UNTUK MENINGKATKAN RESPONS MOTIVASI DAN HASIL BELAJAR SISWA DI SMP NEGERI 4 SURABAYA," J. Educ. Dev., vol. 7, no. 3, p. 278, 2019.

[4] J. N. Calimag, P. A. Mugel, R. S. Conde, and L. B. Aquino, "Ubquitous learning environment using android mobile application," Int. J. Res. Eng. Technol., vol. 2, no. 2, pp. 119-128, 2014.

[5] J. Gikas and M. M. Grant, "Mobile computing devices in higher education: Student perspectives on learning with cellphones, smartphones \& social media," Internet High. Educ., vol. 19, pp. 18-26, 2013, doi: https://doi.org/10.1016/j.iheduc.2013.06.002.

[6] A. H. Elyas, "Penggunaan Model Pembelajaran E-learning dalam Meningkatkan Kualitas Pembelajaran," War. Dharmawangsa, no. 56, 2018.

[7] A. R. Yunianto, "Implementasi E-learning Berbasis Kelase Sebagai Sumber Belajar (Studi Kasus Siswa Kelas X Jurusan Multimedia Di SMK Bagimu Negeriku Semarang)." UNIVERSITAS NEGERI SEMARANG, 2015.

[8] T. M. Fuadi, R. Musriandi, and L. Suryani, "COVID-19: PENERAPAN PEMBElajaran DARING DI PERGURUAN TINGGI," J. Dedik. Pendidik., vol. 4, no. 2, pp. 193-200, 2020.

[9] A. Widiyono, "Efektifitas perkuliahan daring (online) pada mahasiswa pgsd di saat pandemi covid 19," J. Pendidik., vol. 8, no. 2, pp. 169-177, 2020.

[10] M. Nakayama, K. Mutsuura, and H. Yamamoto, "Impact of Learner's Characteristics and Learning Behaviour on Learning Performance during a Fully Online Course.," Electron. J. e- Learning, vol. 12, no. 4, pp. 394-408, 2014.

[11] D. H. Schunk, J. R. Meece, and P. R. Pintrich, Motivation in education: Theory, research, and applications. Pearson Higher Ed, 2012.

[12] Y. Fitriyani, I. Fauzi, and M. Z. Sari, "Motivasi Belajar Mahasiswa Pada Pembelajaran Daring Selama Pandemik Covid-19," J. Kependidikan J. Has. Penelit. dan Kaji. Kepustakaan di Bid. Pendidikan, Pengajaran dan Pembelajaran, vol. 6, no. 2, pp. 165$175,2020$.

[13] J. Lee and L. Martin, "Investigating students' perceptions of motivating factors of online class discussions," Int. Rev. Res. Open Distrib. Learn. IRRODL, vol. 18, no. 5, pp. 148$172,2017$. 
[14] D. H. Schunk and E. L. Usher, "Social cognitive theory and motivation," Oxford Handb. Hum. Motiv., p. 11, 2019.

[15] N. K. S. Astini, "Tantangan Dan Peluang Pemanfaatan Teknologi Informasi Dalam Pembelajaran Online Masa Covid-19," Cetta J. Ilmu Pendidik., vol. 3, no. 2, pp. 241$255,2020$.

[16] M. B. Miles and A. M. Huberman, Qualitative data analysis: An expanded sourcebook. sage, 1994.

[17] B. H. Khan, Managing e-learning: Design, delivery, implementation, and evaluation. IGI Global, 2005.

[18] E. Mulyasa, "Manajemen berbasis sekolah: konsep, strategi dan implementasi," 2004. 